\title{
BLACK THEOLOGY OF LIBERATION AND RADICAL DEMOCRACY: A DIALOGUE
}

\author{
Vuyani Vellem \\ Director of the Centre for Public Theology \\ University of Pretoria
}

\begin{abstract}
Radical Democracy proposes that capitalism should be theorised deeply and furthermore, that the liberal tradition must not be denounced and rejected by the Left. It is possible that what seems to be a 'confusion,' or 'confoundedness,' 'diffusion' and 'vicious' co-optation of liberation symbols since the demise of Apartheid, the fall of the Berlin Wall and the collapse of the Soviet Union could be unravelled with this theory of Radical Democracy. More importantly, Black Theology of Liberation and its symbiosis with Black Consciousness - having assumed that socialism rather than capitalism was an appropriate historical project of obedience to the Gospel of Jesus Christ - must urgently engage Radical Democracy in order to deal with the rhetoric of liberation that is becoming increasingly sterile. This article argues that Black Theology of Liberation must move beyond reasserting, or rearticulating its core values by recommitting itself to social analysis - mokgwa wa yona (its very nature) - and relate to social theories of the reality of our current context. Radical Democracy is thus chosen as a conversant to examine our social reality post-1994 and to identify lessons that could be drawn from this theory.
\end{abstract}

Key Words: $\quad$ Black Theology; Liberal Discourse; Pragmatism; Radical Democracy; Social Theory

\section{Introduction}

The main purpose of this article is to engage the school of Radical Democracy in dialogue with Black Theology of Liberation. The qualification or descriptor 'radical' in relation to democracy could easily suggest a broad field that might be difficult to demarcate; therefore this article focuses on Radical Democracy ${ }^{1}$ as defined by Ernesto Laclau and Chantal Mouffe. The conversation with Radical Democracy is important because Black Theology of Liberation itself has often been understood and described as a 'radical' school of theology. ${ }^{2}$

At core is Radical Democracy's proposition that the liberal democratic ideology should not be denounced by the Left. Clearly, the articulation of the struggle within the liberal tradition poses a number of questions - for Black Theology of Liberation in particular. At

To distinguish the school, I use capital letters so as to distinguish my use of both terms each time they are not rendered in capital letters.

2 For example see this article with this clear descriptor by Heltzel, PG 2009: "Radical Evangelical Democracy: The Dreams and Nightmares of Martin Luther King, Jr. and Antonio Negri," in Political Theology 10 (2): 287-303. In this article, Martin Luther King's theology is presented as radical theology. Exponents of Black Theology will know how James Cone also uses Martin Luther King Jr, Malcom X and the Blues to develop his model of Black Theology. The point is simply that Black Theology of Liberation could be qualified with this same descriptor: 'radical.' 
foundation level Black Theology of liberation has been critical of the liberal tradition surely because of the former's intrinsic link with Black Consciousness. ${ }^{3}$ In this article, some of the implications of Radical Democracy are discussed tentatively in order to examine whether there could be cleavages between the 'radicality' of democracy as perceived by Laclau and Mouffe, and Black Theology of Liberation which "may be called a theology of revolution" (Cone 1969:32). One of our aims, emanating from the comparison between Radical Democracy and Black Theology of Liberation, is to argue, if not demonstrate that social theory is an important tool without which Black Theology of Liberation cannot succeed in post-1994 South Africa.

Indeed, in the context of what seems to be a 'confusing' state about the so-called Left and Right in our South African politics, since the collapse of the Soviet Union, the demise of the socialist project in the main and Apartheid as well, social analysis remains indispensable to unlock the theme of deepening the liberal discourse rather than denouncing it, as proposed by the Radical Democracy school. It is important also to help us answer some of the shifts we have seen so far, where those who have been identified as ideologically critical and opposed to liberalism, seem to have found a way to operate in spaces that are vividly liberal in orientation and ideology. Our use of the word 'confusing,' to describe the post-1994 context whose economic policy framework has been undeniably neo-liberal, seemingly supported by Leftist exponents, emanates from this context in which ideological demarcations are no longer easy to make.

\section{Social Theory and Social Analysis in Black Theology of Liberation}

Since the development of the liberation paradigm in theology, associated with the Latin American Liberation Theology, Black Theology of Liberation in North America and South Africa, African Theology, Minjung Theology in Korea, Dalit Theology in India, Feminist and Womanist Theologies - captured in the past as Third World Theologies - there emerged a methodological difference between Western Traditional and Liberation theologies.

This methodological difference designated by some (Tefsai 1996) as the debate between Liberation and Orthodoxy, distinguishes the vision, starting points, contours and goals of doing theology between the two schools. For example, while Orthodox theology sees the non-believer as its interlocutor, the Liberation paradigm has continued to argue that the non-person is its interlocutor. Gustavo Gutierrez says, "...we referred to the poor as nonpersons" (2007:4) and earlier on Boesak (1977:26) employed the same category of nonperson to elucidate the concept of 'blackness,'i.e., the interlocutor of the liberation paradigm of doing theology. There is a huge distinction between the goal of a theology that sees its interlocutor as the non-believer and another whose interlocutor is the non-person. In the liberation paradigm, the situation of the non-person and thus situation analysis is one of the key tenets of doing this model of theology.

James Cone, after more than forty years since the publication of one of the foundational texts in the school: Black Theology of Liberation (1969), has continued to argue even more aggressively in his most recent work: The Cross and the Lynching Tree (2012), that the incompatibility between Orthodox and Liberation theologies arises from differences in

Those who are familiar with the school of Black Theology of Liberation in South Africa will remember that one of the doyens of the school, Itumeleng Mosala, was also the President of the Azanian People's

Organization (Azapo) which was and continues to be a socialist oriented political movement. 
priority questions and silences by the former on issues that are existentially significant to the latter. For this reason, Cone (1969:117-118), having asserted the need for the analysis of the situation of a black person as an important task for practising theology, continues to hold that the questions Black Theology of liberation prioritises are different from those prioritised by White theology, and by implication, Orthodox theology. The conversation in this article is based on this understanding of practising theology, aptly described by Cornel West when he says, "The possibility of liberation is found only within the depths of the actuality of oppression. Without an adequate social theory, this possibility is precluded" (1979:557). Black Theology of liberation therefore is a model of theology that is embedded in the depths and actualities of oppression. For this reason, it is a model of theology that requires adequate social theory in its analysis of the depths and actualities of oppression.

In South Africa, the importance of social analysis later found expression in the various phases of development in the school of Black Theology of Liberation. One of the most telling and pertinent of its phases was the debate between the Racial and Marxist strands in Black Theology of Liberation. ${ }^{4}$

Julian Kunnie (1994) argued for a radical social analysis too by proposing folk tales as a prism for this purpose - the analysis of the experience of oppression. It is also stated clearly in the Kairos Document that social analysis is a requirement for Prophetic Theology. We conclude therefore, that without social theory, which is indispensable for social analysis, we cannot effectively theorise and reflect on the power changes and shifts that have occurred since the fall of the Berlin Wall, the demise of the USSR and Apartheid and the end of the Cold War - the $21^{\text {st }}$ century, in short. The motivation to engage the theory of Radical Democracy stems inter alia from this background. Radical Democracy does not reject capitalism, and Black Theology of Liberation has not accepted capitalism; nor has it theorised its relationship with capitalism adequately. The critique of Black Theology of Liberation by Ivan Petrella, to which I now turn, sheds more light on this aspect of the discourse.

\section{Beyond the Reassertion, or Rearticulation of Black Theology of Liberation}

One point of criticism levelled against Liberation Theology by Ivan Petrella in his book: The Future of Liberation Theology is that reasserting and rearticulating the core themes of this paradigm, albeit important, is no longer adequate in the $21^{\text {st }}$ century. In his specific discussion of 'Liberation and Capitalism' he explicitly alludes to the problem of undertheorising or better, the failure to ground arguments against capitalism on social theory (2004:69). Petrella continues to argue that the conceptualisation of capitalism by liberation theology continues to be a hindrance to the liberation paradigm itself to develop new historical projects (2004:69). Most pertinently for this article is the appeal Petrella makes to Fernando Cardoso, that "Capitalism must be, and can be through the right combination of policy and struggle, reworked into socialism," (2004:73). This is exactly what Laclau and Mouffe argue, and Petrella seems to suggest that we should theorise capitalism in another way, more so if our task is grounded on social theory.

We take our cue from the sentiments above to argue that one of the reasons we have stifled the feasibility of Black Theology of Liberation perhaps in the post-1994 South

Gideon Khabela offers an enlightening account of this debate in his $\mathrm{PhD}$ thesis, 1992. A Seamless Garment:

Tutu's Understanding of the Role of the Church in South Africa. Doctoral dissertation. New York: Union

Theological Seminary, pp. 282-287. 
Africa is the constant reaction we offer to the external challenges against this school, some of which are caused deliberately. After decades of the existence of the paradigm of liberation in South Africa and the world - and in order for us to avoid being recycled as the contest against this school is unlikely to abate - there is a need to move beyond rearticulating its core values. For this reason I concur with Petrella. We should further take our cue from James Cone, in his discussion of the relationship between faith and praxis, when he says:

While there are different emphases among liberation theologians regarding the major historical contradiction in society, they all agree with the need to relate theology to a social theory of reality, because they share the conviction that truth is found in the active transformation of unjust social structures (1986:46).

To relate our theology to the challenges of the 21 st century requires searching for social theories to which our theological endeavours must be related. The last sentence in the quotation above is even more telling. It is about the importance of history - active participation in the transformation of unjust social structures. It is more important, we note, than differences of emphasis regarding historical contradictions in society. Nonetheless, this is clearly unattainable without any kind of social analysis and a particular view of history. We make this point to justify our purpose, namely, the need to dialogue with Radical Democracy and more broadly, the need for Black Theology of Liberation to heed social theory and thus social analysis in the development of the school. Let us remember that Cone, as much as he turned Karl Barth's theology 'inside-out', also reinterpreted the appropriation of the notion of praxis by equally reversing Dietrich Bonhoeffer's interpretation of faith and obedience.

Accordingly, he sees obedience as a practical starting point, because: "One meets God in the process of historical liberation" (Cone 1986:47). It is when faith is gifted from the struggle for liberation that it might be connected to the "prevenient grace of God," he argues (Cone 1986:49). First, there is an agreement at least among all liberation theologians to relate their theology to social theories of reality. Second, truth erupts in the active transformation of unjust social structures. ${ }^{5}$ With these tenets of Black Theology of Liberation in mind, the need to go beyond re-articulation or reassertion to identifying social theories that might assist us interpret our current reality could not be overstated. The task to identify relevant and critical theories has therefore become too serious to overlook. The perpetual co-optation of the tenets of Black Theology of Liberation even by its worst adversaries makes this task much more imperative.

Ivan Petrella makes this very point when he challenges Latin Liberation Theology to move beyond asserting and revising its core values to participating in the construction of a historical project. Obedience, à la Cone, is in praxis, and God and God's grace, according to Black Theology of Liberation is met in the struggles of historical liberation.

Indeed, the crucial relationship between theology and social science must be a wellknown fact. Cone asserted many years ago that Black Theology of Liberation is "a

The participation of the church in the struggle was motivated mostly by this understanding for a faithful participation in the structures of injustice in South Africa. This is what distinguished Black Theology paradigmatically from Political Theology and the use of Marxist tools by numerous exponents of Black Theology of Liberation and is adequate testimony in support of this point. We can only recall the debates between the Race and Materialist strands of Black Theology of Liberation to illuminate the point. We have alluded to Khabela, but cf. also, Ntintili, V. 1996. "Notions of Liberation in Black Theology: Which is more Liberative?" in Journal of Black Theology, Vol.10, No.1:1-18. 
conscious investigation of the socio-religious experience of the black people" (1977:16). "Social context is important" (1977:43) he explained, and we add, fundamental to liberation theology, meaning that what people think and say about God, Jesus and the church is difficult to separate from their social and political locations.

That "consciousness is a social construction" (1977:46) is core to the paradigm of Black Theology of Liberation and other models of liberation theology. For this reason, the need to participate in the construction of historical projects is not foreign to the heritage of liberation even though it appears to have disappeared in the post-1994 political context of South Africa. That these core tenets of the liberation paradigm continue to be co-opted even by the champions of neo-liberal institutions in vain, as most of them are not even committed to the ideals of radical transformation and equality - should be enough reason for us to worry. This point, we should remember, was made eloquently by Tinyiko Maluleke and Sarojini Nadar (2004) when they argued poignantly that there is a 'fraudulent' discourse of the co-optation of liberation tenets in South Africa. While the versatility of liberation knowledge could be viewed as a strength, it is not only by rearticulating, or reasserting liberation knowledge that the tradition of Black Theology of Liberation can thrive, when this game of 'fraudulence' in the $21^{\text {st }}$ century has shifted to a pseudo-religious crusade, shamelessly poised to conquer the whole of social life and to suspend history through its convergence of power, money and military violence. ${ }^{6}$

To defend the heritage of Black Theology of Liberation from any fraudulent co-optation of its symbols and grammar - we insist - requires a tenacious commitment to social analysis and thus, social theory.

To illustrate the points argued thus far, the contradictions on liberation knowledge are clarified by current analyses of the socio-political context post-1994. Kwandiwe Kondlo (2011) offers a sharp criticism against the South African Communist Party (SACP) in post1994 politics. Apart from what he designates a "tired rhetoric of the Left," the eclecticism of the Party and the sterility of the vanguardist notion of liberation in his critical analysis of the SACP, he pleads for serious attention to these weaknesses. He makes this overall contention:

I would have no problems if the SACP restates its agenda to say it does not seek to renounce liberal democracy but instead seeks to deepen and expand it 'in the direction of radical and plural democracy' (Laclau \& Mouffe 2001).

This offering to the SACP to follow the direction of 'radical plural democracy' is our fascination in this article. The sentiments above ostensibly arise from what seems to be painfully true in our South African public life, namely that the difference between a capitalist and a communist is so diffuse today. For example, those who have opposed Julius Malema's project of 'economic liberation in our life-time' have often pointed to the contradictions of his lifestyle. They argue that it is necessary for those committed to the poor to identify with them and their cause by choosing a particular lifestyle. Strangely, the same critics are not necessarily outside of the 'Gucci' and obscene lifestyles of wealth display for which they criticise Malema. Yet the issues that are raised by Malema appeal to the masses of the poor and the millions of the youth that are unemployed. After having

6 There is already much literature on Empire and the Accra Confession is one of those symbolic Reformed contributions against Empire across the globe. Cf. VS Vellem "Convergence and Eschatology: A Black Theological View of Globalisation and the Rise of 'Revival Churches,' a paper delivered in the Democratic Republic of Congo in 2011 and upcoming, particularly the notion of the convergence of public spheres and its impact on public life." 
been expelled by the African National Congress (ANC), Malema has now established a party, the Economic Freedom Fighters, (EFF) and contested elections in 2014 with the same arguments he advanced while he was President of the Youth League of the same organisation.

This example is made to point to the contradictions in the ANC, which has - perhaps for wrong reasons - been identified as a Leftist organisation in opposition to liberal politics. Does the ANC renounce liberal democracy? This is the question and our argument is that we could probably respond to this question, or even debate this question meticulously through social analysis and thus the theoretical assumptions that undergird the choices the ANC has made in post-1994 democratic South Africa.

Another example is that of the General Secretary of the SACP, Dr Blade Nzimande, who is the current Minister of Higher Education in South Africa. Ever since his appointment as a cabinet Minister, he has had to find reason to justify the dual role he plays in public life as a leader of the Left and a Minister with a Ministerial Handbook that 'defines' his lifestyle.

Arguments for him to choose between the two positions have not ceased and time and again he has had to find ways to explain this matter in his public speeches. It is not the merits of the positions we have highlighted above that is the bone of our contention for now, but the contradiction inherent in these examples in so far as the traditional ideological demarcations that sought to distinguish those who are committed to the poor from the rest have been understood hitherto. The looming wreckage in the Congress of South African Trade Unions (Cosatu) and the internal debates on the National Development Plan (NDP) and the Youth Wage subsidy among others, serve as good examples of what we have designated as a 'confusing' state in our public life, arising from signals that seem to contradict the positions traditionally held by some individuals or even organisations in the struggle for liberation.

Kondlo's point becomes more pertinent when he points to the structural shifts that took place since 1989 in the world. He argues that these shifts have contributed to the 'heteronomous' and 'autochthonous' discourses of politics. By these two terms, 'heteronomous' and 'autochthonous' he means respectively, that since the fall of the Berlin Wall, politics has become too pragmatic with the sovereignty of the state simultaneously diminishing - becoming autochthonous. Because of the saturation of pragmatic discourse of politics in a heteronomous state, theoretical and intellectual discourses are eclipsed if not muzzled, he argues. The power of the state is also diminishing increasingly, i.e. many states are gradually losing their sovereign power since the fall of the Berlin Wall.

In this context of saturated pragmatic politics, a context in which ideological contests and demarcations are so diffuse, confounding and unclear, democracy becomes a tool of the elitist, too detached from the aspirations of the poor masses.

This is implied by Xolela Mangcu in his critical view of the 'elite fear of democracy' and the trade unions in South Africa that can no longer speak for the underdog (2009:29-31).

The politics of pragmatism muzzles the intellectual discourses once committed to the plight of the poor, while the elitist groups continue to dominate the political discourse of the country.

There may be similar charges against Black Theology of Liberation. Since the demise of Apartheid in South Africa, many negative things have been said or implied about this intellectual tradition. One should not be worried about the onslaught against Black 
Theology of Liberation, whether subtle, or overt! We should rather be worried about a Black Theology of Liberation that might be 'saturated with pragmatism' and contradiction, destined to compromise its 'sovereignty,' thus becoming a tired rhetoric of liberation in public life. We should be far more worried about the possibility of a charge against this school that it 'speaks left when it walks right.' It is not a secret that at foundational level, Black Theology of Liberation, due to its affinity with Black Consciousness, could arguably be located within the Leftist project of socialism by some of its exponents. For example, Nkosinathi Biko writes:

The political space of which Steve Biko was a part has seen a number of 'isms' turned on their heads. In the past, the predominant discourse was that of socialism versus capitalism. In what would have been the year of his retirement (Steve Biko), central banks around the world are arguing that they need to apply a little socialism in order to rescue capitalism (2012:1).

Indeed, in the past Black Theology of Liberation, generally speaking, identified with the Left, socialism perhaps being preferred to capitalism, the point we have already made. Biko argues that today banks apply a little socialism in order to rescue capitalism. Indeed, the language of liberation is employed even at that level. Now, can a little capitalism rescue socialism? This is the question to reiterate for our conversation.

We should be careful with this generalisation in the light of what Itumeleng Mosala postulated some years ago: "that a plurality of black theologies of liberation is a reality of the contemporary South African situation as influenced and shaped by black history and culture in addition to bourgeois society" (1989:190-191). It is therefore important for us to grasp at this very point that there have been many brands of Black Theology of Liberation. Tinyiko Maluleke made a similar point:

The decision to encourage diversity in ideological frameworks in the doing of Black Theology was taken more than a decade ago (1983, 1984 Black Theology conferences). This diversity is evident in some of the writings of Black theologians in the past decade. What theologians such as Mosala (1985:109) have, however, insisted upon is that "the question of ideological framework is of vital importance in any attempt to participate in a theology of liberation". This must not be confused to mean that one ideological framework is better than all others (Maluleke 1995:22).

In this regard one should be soberly conscious of the diverse ideological positions that might be associated with the school. At the same time, the vital importance of ideology, clearly linked to a particular social theory, is indispensable to those who do Black Theology of Liberation. Our focus for this dialogue, nonetheless, is on that brand which, as seen by Mosala, "consciously adopts a black working-class perspective" (1989:191). Perceived as the most liberative and comprehensive of the brands of Black Theology of Liberation, this one which adopts the working-class perspective obviously places the proletariat as the agent of change, a significant point of dialogue with Radical Democracy. At least, secondary to the thrust of this article, must be a clear need for social analysis in order to engage whatever diverse ideological frameworks there are in the school itself or in the liberation movement.

Following this point above, Nkosinathi Biko suggests that the powerful of this world can, when it suits them, co-opt socialism, i.e., the tools of the working class perspective of Black Theology of Liberation. The collapse of the Berlin Wall and the historical fiasco of the socialist project and the evident co-optation of the socialist tools by the central banks must remain a challenge to Black Theology of Liberation to the core! 
For this reason, it may ultimately be inexcusable for Black Theology to refrain from dialoguing with new insights that reflect on the tension between capitalism and socialism, or better, liberty and equality discourses in the $21^{\text {st }}$ century. The theoretical and intellectual discourse of the school may become sterile in a context of structural pragmatism and contradictions in public life. The co-optation of the tools of socialism by the liberal project adds its own dimension to the sterility of the liberation project. How does Black Theology of Liberation move beyond rearticulating or renouncing its positions for meaningful engagement with liberal democracy and the contradictions that are prevalent since the demise of Apartheid? Let us turn to Radical Democracy with this question in mind.

\section{Radical Democracy: Alternative for a New Left}

This subtitle above is the exact title of an article written by two leading scholars in the field of Radical Democracy, Ernesto Laclau and Chantal Mouffe in 1985. We should state upfront that their writings, which I am constantly quoting, are rather intellectually challenging - a situation which finds its parallel in a remark once made by Maluleke, namely that the Marxist tools are "...excellent theories ... [but] the protestations of its adherents are often difficult, if not impossible, to translate for mass benefit and consumption" (1996:34).

This does not mean that he denies the liberative potential of these theories; long ago Takatso Mofokeng expressed similar sentiments about Marxism vis-à-vis the importance and centrality of the Bible among the poor, which in our South African context may arguably be the only weapon in their hands for their liberation struggle. ${ }^{7}$ Notwithstanding these cautionary views, our attempt is to delve into the foundational level and propose that such intellectual tools espousing a socialist, Leftist option (to which Black Theology of Liberation has been known to be committed, no matter how difficult) deserve attention. Radical Democracy is one such a social theory with which we need to dialogue more because its proponents have also been known to be Marxists.

Laclau and Mouffe argue that as an alternative for the Left, they locate themselves fully in the field of democratic revolution. They explicitly state that:

The task of the Left therefore cannot be to renounce liberal democratic ideology, but on the contrary to deepen and expand it in the direction of a radical and plural democracy (Laclau and Mouffe 2010:492).

This is what is at the core of Radical Democracy, the deepening and expansion of liberal democracy rather than its denunciation. Known to be Marxists themselves, they criticise the deterministic nature of Marxism and point to the failure of the Left to contend with the shifts, or displacements of what they call nodal points that structure social formation which are important to locate for liberation struggles. Due to a dogmatic view of class analysis, these shifts or nodal points elude the Left. They argue that classism, "the idea that the working class represents the privileged agent in which the fundamental impulse of social change resides" is an obstacle. Against this dogmatism, which in their view leads to what they designate as 'essential fixity,' they posit that a deeper understanding of the notion of revolution might be helpful to disentangle the Left from its weaknesses.

Gerald West has used this argument in his paper entitled: 'Mbeki's Bible'. He suggests that Mbeki's use of the Bible derives from the conscious knowledge that the masses of the people of this country rely more on the Bible than on Marxist tools in their quest for liberation. 
For example, they argue, revolution is foundational, it instantiates a new concentration of power around which society could be newly reorganised. Revolution is a process which has both internal and external moments. In the process of revolution therefore, the multiplication of political spaces that prevent the concentration of power in one point then become conditions for democratic transformation. Let me allow them to speak:

The classic conception of socialism supposed that the disappearance of private ownership of the means of production would set up a chain of effects which, over a whole historical epoch, would lead to the extinction of all forms of subordination. Today we know that this is not so (in Lemert 2010:493).

These sentiments are too important to ignore. Private ownership has not disappeared even though there have been successful struggles against subordination. If rather than the disappearance of private ownership, socialism itself disappears, what then will replace it for the eradication of private ownership? Can we deny that there have been chains of effect that combined, leading to the extinction of sexism and gender oppression while capitalism remained intact? they ask. In other words, have no struggles been waged and won over subordination while at the same time leaving capitalism untainted? These are the questions directed mainly against the classical view of socialism, the deterministic, essentialist view of socialism and classism.

Radical Democracy, does not reject socialism; rather, their exponents perceive socialism as one of the components of Radical Democracy, not the other way around. The anti-democratic features of socialism are repudiated, while liberal democracy is not rejected, but targeted wherever the possibilities of Radical Democracy exist. According to Anna Marie Smith, the rights discourse dubbed "generative principles of democracy" should be embraced, as progressive instances of the liberal democratic moments" (1998:5). Smith argues that human rights can incite the emancipatory struggle even though that discourse is originally bourgeoise. She says:

Marxist discourse privileges class as the primary form of social agency and capitalist exploitation as the primary form of domination. It is, in this sense, an essentialist discourse that cannot grasp the irreducible multiplicity of oppressive power relations; only an anti-essentialist discourse can perform this task (1998:41).

Radical Democracy simply rejects anti-democratic elements in socialism, while it retains the Marxist critique of liberal politics without rejecting the emancipatory and generative principles of democratic revolution in liberal politics. What can one make of this argument in explicit terms? The argument probably suggests that Black Theology of liberation should not denounce liberal democratic ideology because according to the school of Radical Democracy, liberal discourse on individual rights is not fixed. It might be an error to fix individual rights to the liberal discourse in the same way as it was for the Marxist tradition to fix its praxis on class. So, liberal democracy should be denounced on the pivot of individual rights as many critiques sought to treat it.

There is a sense also in which one might understand Radical Democracy as placing liberal discourse and socialism as its components; in other words, Radical Democracy is not a component of socialism, but above it and in this sense, above liberalism. Democracy cannot be abandoned in favour of socialism. This presents our attempt to interpret the meaning of Radical Democracy. So in the end, could Radical Democracy offer a possibility of liberation within the depths of the oppression of millions of South Africans since the dawn of democracy in this country? Let us see whether there are lessons that can be drawn from what we have understood so far as Radical Democracy. 


\section{Tentative Lessons of the Dialogue}

There are mutual lessons both schools can learn from each other - Black Theology of Liberation and Radical Democracy.

That there are strong affinities between the two schools enriches the language and symbols of liberation in the post-1994 political dispensation and the global stage of power contestations in the $21^{\text {st }}$ century. The fact that there are anti-democratic fault lines in both the socialist and the liberal discourses is not only refreshing, but pivotal for the critical role that Black Theology of Liberation can play in post-Apartheid South Africa. Importantly, Radical Democracy takes language seriously in the formulation of anti-totalitarian discourses. It argues that the liberal discourse creates new definitions and changes terms to erode the gains of the liberation struggle. This point captures what Black Theology of Liberation has decried as the co-optation of the liberation symbols.

At another point Laclau and Mouffe distance themselves from Habermas, whom they perceive to conjure a rationality of 'pre-established universality' (Buttler et al. 2000:3). This must reinforce the position Black Theology of Liberation has taken against universalism. Itumeleng Mosala (1989) offers a good example in his analysis of the tensions between universality and particularity for black hermeneutics. Terry Eagleton's views on universality are also relevant: he argues that for some universality has meant that the West is the sole bearer of universal values and places capitalism in our globalising world as one value that has ousted every space and everyone today. According to him the values of equality find expression in the myths of equality promised by the market in the globalised world (2009:72-73). These twisted values of universality demonstrate the dilemmas that the pre-established universality of Western discourse often imposed on Black Theology of Liberation.

So in the critique of universality there is convergence between Black Theology of Liberation and Radical Democracy and indeed there is a mutual and reciprocal borrowing of concepts and language in this regard. Importantly, there is a caution here for Black Theology of Liberation itself to be sensitive to conjuring up disguised universalities obviously implied in the fixed dogmas and essentialism that might have hampered its development.

On the question of interlocution, Ernesto Laclau's review of the notion of populism in his book On Populist Reason traces the disintegration of the psychological currents of theories of crowd psychology (2007:39). Laclau delves into the Freudian categories of social theory to demonstrate how the notion of crowd and its psychology has been developed and viewed to be distinct from 'public,' with the notion of public being construed as a body "whose cohesion is mental" (2007:44). 'Populism' he argues, has been connected to a 'dangerous excess,' in the past (2007:X). The language provided by Laclau in this regard, particular the statement about populism as being "a way of constituting the political" (2007:X), reinforces the long-held view in Black Theology of Liberation of the experience of the non-person as the necessary starting point for theology. This is a rich point of dialogue particularly because of the resources he employs to argue his point. Laclau himself affirms the Fanonian 'wretched of the earth' which resounds tout court with Steve Biko's tradition of Black Consciousness, integral to Black Theology of Liberation.

As a digression of the three Greek words that are used to refer to people in the New Testament, ochlos seems to be the category with which Jesus identified rather than laos and ethnos. The ochlos are these crowds in the Bible, the riff-raff of society, the underdogs, the lumpenproletariat as Marx defined them, who are the 'excesses' of society destined to be 
'far away from civilisation.' This is the category that defines the 'disdainful' notion of 'blackness,' the non-person to whom Black Theology of liberation seeks to deliver the liberating message of the Gospel of Christ. To recapitulate the main point we are making in this section, we are still considering Laclau's development of his theory of populism and its resonance with Black Theology of Liberation. In other words, Radical Democracy is an agonistic theory of democracy in conflict with some tenets of the liberal discourse, while reformulating it together with the socialist project. Dare we say that Radical Democracy seeks to 'colonise' the liberal tradition into the Left? Well, further dialogue with Radical Democracy is necessary, but for our purpose, we have attempted to identify gaps between the schools in the light of our major argument in this article, namely, the need to pursue the gains of the liberation paradigm through social analysis and social theory. Radical Democracy sheds some light on what we have designated a 'confusing' state in our context of democracy in South Africa, but there are divergences.

\section{Some Differences between Radical Democracy and Black Theology of Liberation}

There should obviously be some careful distinction between the two schools. Deepening the liberal discourse rather than denouncing or renouncing it must still contend with the fact that the French Revolution to which the liberal discourse is ultimately traced, may not stand as an alternative vision of liberation than the Haitian Revolution for Black Theology of Liberation. The Haitian Revolution may not necessarily be chosen for the sake of making choices, but simply because it is not mainstreamed; yet the two erupted almost at the same time. Moreover that the translation of the gains of the liberal discourse from the West to Africa did the opposite, remains one of the striking quagmires one has to contend with continuously. The black African experience, up to this day, continues to be a festering wound inflicted by those who benefited from the virtues of the liberal discourse upon arriving on the continent in our land South Africa. It is difficult to place the liberation vision on the traditions and values that were enjoyed by those who used them as bitterest sources of oppression and subordination in the non-Western worlds.

Mahmood Mamdani (1996) has already made a point we cannot overlook about the language of human rights. He cautions that this language often takes the discourse of justice two steps backward. Indeed if the liberty discourse is seen as a replacement of equality and justice, and thus the abandonment of socialism, then deepening the liberal tradition can be dangerous. Often, this ensues when an attempt is made at deepening both of these traditions simply because one has become powerful and cunning by co-opting the symbols of the other in a parasitic manner. Mahmood Mamdani's insights remain invaluable for the deepening of liberal politics to include equality, while the socialist paradigm is equally denuded of its anti-democratic weaknesses.

There is an important point that probably defeats the undeniable pivotal point of Radical Democracy, viz. that nodal points often change as a result of variable political spaces that emerge due to revolutions. For this reason, the argument goes, agents of change should not be determined a priori, as the Left sought to argue. Stated otherwise, one could say that Radical Democracy suggests that true democratic transformation occurs when there are multiple political spaces that inevitably prevent the concentration of power in one point. However, Black Theology of Liberation follows what Jesus Christ himself taught, and the choices he made to side with the poor. This is the nodal point for any struggle even when there are multiple spaces of radicalism: the mystery of the preferential option for the poor. 
Ultimately, for Black Theology of Liberation the question is whether there could be any compatibility between capitalism and the gospel of Jesus Christ.

\section{Conclusion}

The relationship between Black Theology of Liberation and social science, ka mokgwa wa yona (its manner of doing theology), is no longer a luxury, but an essential to traverse the vicious and tempestuous terrains of socio-political and economic theories in the $21 \mathrm{st}$ century challenges. The co-optation of liberation tools and the saturation of pragmatic politics not only diffuse and confuse the boundaries of ideological contestations in South African public life and the globe, but also challenge Black Theology of Liberation to move beyond rearticulating its core values as a strategy. If there is a social theory that justifies embracing the liberal tradition in the same manner as the Radical Democracy school then Black Theology of Liberation cannot lament, but engage this theory and probably even have a better grasp of the seismic power shifts that have occurred in the 21 st first century.

There are many lessons that can be harnessed from the Radical School of Democracy, one of which is the deepening of the liberal discourse through the generative principles that are located in both liberty and equality projects. Clearly, the socialist project of equality cannot be abandoned; rather the anti-democratic antics of both the liberal and social discourses must be repudiated. Indeed, after 20 years of democracy, are there no signs of anti-democratic practices within the former liberation movements and organisations that were regarded as exponents of the liberation struggle? This task of unveiling antidemocratic practices, particularly in relation to our Leftist discourse, is urgent today. If the 'crowds,' the lumpenproletariat, the millions of the poor who are unemployed, including those on state grants and the masses who are on service delivery strikes are sheer 'excesses' of the political settlement after Apartheid, then it is not their exclusion, but their participation in democracy that will provide radical tools with new nodal points of revolution to reclaim democracy itself to the people.

There are, however, important convergences and divergences between the schools. The French and the Haitian Revolutions point to the 'yes' and 'no' relationship that Black Theology of Liberation will continue to have with Western traditions. Whether Rightist or Leftist, Black Liberation Theology remains a discourse shaped by the festering wounds of those living in the trenches and dungeons of impoverishment by the West. This is not a fixed position of Black Theology of Liberation, but a revelation from the Cross of Jesus in whose obedience the preferential option for the poor remains the locus of the manifestation of God's grace.

\section{BIBLIOGRAPHY}

Biko, N 2012. "Quest for a True Humanity - Achieving the Vision.” Frank Talk, Issue 2, www.sbffranktalk.com, p 1.

Butler, J, Laclau, E \& Žižek, E 2000. Contingency, Hegemony, Universality. London, New York: Verso.

Cone, JH 1975. God of the Oppressed. New York: Seabury.

Cone, JH 2013. The Cross and Lynching Tree. New York: Maryknoll, Orbis.

Eagleton, T 2009. Reason, Faith and Revolution: Reflections of the God Debate.

New Haven, London: Yale University Press. 
Gutiérrez, G 2007. "Liberation Theology for the Twenty-First Century," in Closkey, PH \& Hogan, JP. Romero's Legacy: The Call to Peace and Justice. Maryland: Rowman and Littlefield, 1-40.

Heltzel, PG 2009. "Radical Evangelical Democracy: The Dreams and Nightmares of Martin Luther King, Jr. and Antonio Negri." Political Theology 10 (2):287-303.

Laclau, E 2005. On Populist Reason. London: Verso.

Lemert, C 2010. Social Theory: The Multicultural and Classic Readings (4th Edition). Philadelphia. Westview Press.

Khabela, G 1992. A Seamless Garment: Tutu's Understanding of the Role of the Church in South Africa. Doctoral dissertation. New York: Union Theological Seminary.

Kondlo, K 2011. "At the Point of a Needle: The South African Communist Party and the Dilemma of the National Democratic Revolution in South Africa, 1994 to date." Inaugural Lecture, Centre for African Studies, University of the Free State.

Kunie, J 1994. Models of Black Theology. Issues in Class, Culture and Gender. Pensylvannia: Trinity Press International.

Lummis, CD 1996. Radical Democracy. New York. Cornell University Press.

Maluleke, TS 1995. "Black Theology lives! - on a permanent crisis." Journal of Black Theology in South Africa, 9/1:1-30.

Maluleke, T \& Nadar, S 2004. "Alien Fraudsters in the White Academy: Agency in Gendered Colour.” Journal of Theology for Southern Africa, Vol.120:5-17.

Mangcu, X 2009. The Democratic Moment: South Africa's prospects under Jacob Zuma. Auckland Park: Jacana Media (Pty) Ltd.

Ntintili, V 1996. "Notions of Liberation in Black Theology: Which is more Liberative?" Journal of Black Theology, Vol.10, No.1:1-18.

Petrella, I 2004. The Future of Liberation Theology - An Argument and Manifesto. Hampshire: Ashgate Publishing Limited.

Smith, AM 1998. Laclau and Mouffe: The Radical Democratic Imaginary. New York. Routledge.

Tefsai, Y 1996. Liberation and Orthodoxy. The Promise and Failures of Inter-confessional Dialogue. New York: Maryknoll, Orbis. 